\title{
QUEEN'S
UNIVERSITY
BELFAST
}

\section{A European Culture War in the Twentieth Century? Antic-Catholicism and Anti-Bolshevism between Moscow, Berlin, and the Vatican 1922 to 1933}

Weir, T. (2015). A European Culture War in the Twentieth Century? Antic-Catholicism and Anti-Bolshevism between Moscow, Berlin, and the Vatican 1922 to 1933. Journal of Religious History, 39(2), 280-306. https://doi.org/10.1111/1467-9809.12185

Published in:

Journal of Religious History

Document Version:

Early version, also known as pre-print

Queen's University Belfast - Research Portal:

Link to publication record in Queen's University Belfast Research Portal

\begin{abstract}
Publisher rights
(C) 2014 The Author.

This is the pre-peer reviewed version of the following article: Weir, T. H. (2014), A European Culture War in the Twentieth Century? AntiCatholicism and Anti-Bolshevism between Moscow, Berlin, and the Vatican 1922 to 1933. Journal of Religious History. doi: 10.1111/14679809.12185, which has been published in final form at http://onlinelibrary.wiley.com/doi/10.1111/1467-

9809.12185/abstract;jsessionid=9865D72D3A8EA9458278B784920F870E.f02t01].

General rights

Copyright for the publications made accessible via the Queen's University Belfast Research Portal is retained by the author(s) and / or other copyright owners and it is a condition of accessing these publications that users recognise and abide by the legal requirements associated
\end{abstract} with these rights.

Take down policy

The Research Portal is Queen's institutional repository that provides access to Queen's research output. Every effort has been made to ensure that content in the Research Portal does not infringe any person's rights, or applicable UK laws. If you discover content in the Research Portal that you believe breaches copyright or violates any law, please contact openaccess@qub.ac.uk. 
Presubmission version of article to appear in Journal of Religious History 2015.

\section{A European Culture War in the Twentieth Century? Anticatholicism and Antibolshevism between Moscow, Berlin, and Rome 1922 to 1933}

\section{Todd H. Weir, QUB}

In 1981, historian Winfried Becker argued for an interpretation of the German Kulturkampf of the 1870s within a European context, as one of many conflicts with the Catholic Church that emerged "in the second half of the nineteenth century, wherever the powerfully interventionist centralized national state joined up in the name of progress with contemporary currents that were partly secularistic and partly directly hostile to religion." 1 Not only have comparative and transnational studies integrated the Kulturkampf into the wider history of anticatholicism, ${ }^{2}$ the term "culture war" has been liberated from its German origin and has now been applied as a generic expression for secular-catholic conflicts across nineteenth-century Europe. ${ }^{3}$ Interpreting the parties to these conflicts as "cultures" corresponds to what can be described as a paradigm shift in the study of religion. Rejecting the teleological implications inherent in theories of secularization or modernization, recent studies have shown how conflicts between liberalism and ultramontanism overlapped with existing confessional antagonisms and contributed to the formation of modern party systems and socio-political milieus. ${ }^{4}$ Intellectual and cultural historians have discovered in anticatholicism a discourse and practice through which liberal ideas of subjectivity, sociability, and nation were constructed. ${ }^{5}$

Most studies of the transnational culture wars, like the other essays in this special issue, break off prior to the First World War. Yet, if measured by acts of violence, anticlericalism peaked in the years between 1927 and 1939, when thousands of Catholic priests and believers were imprisoned or executed and hundreds of churches razed in Mexico, Spain and Russia. While the historical literature on anticlericalism in these three countries continues to grow, ${ }^{6}$ there has been little effort to develop a wider theoretical and transnational framework, such as has emerged around the study of the nineteenth century 
culture wars. ${ }^{7}$ This essay sketches out what such an approach might contribute to our understanding of the interwar period, before taking as a case study the interaction of communist and Catholic actors located in the Vatican, the Soviet Union, and Germany in the period between the beginning of the Pontificate of Pius XI in 1922 and Hitler's appointment as chancellor of Germany in 1933.

Why has the investigation of the relationship of anticatholicism to the formation of modern political culture not been extended into the twentieth century, except in the Spanish case ${ }^{8}$ The most obvious answer is that Kulturkampf had simply abated. Historian Martin Conway names several developments in interwar Europe that point in this direction, among others, the inclusion of centrist Christian parties in pluralistic democracies, the weakening of confessional divisions, and the retreat of liberals and social democrats from anticlericalism. Conway considers anticlerical violence to have been a largely marginal phenomenon, limited to Spain or located outside of Western Europe. Thus he suggests that the Vatican's fears of radical secularism, expressed in numerous encyclicals, was a misreading of a largely benevolent postwar environment that either stemmed from the residual trauma of the nineteenthcentury culture wars or provided an instrumental means of rounding up the flock. ${ }^{9}$

While I agree with Conway's points regarding the fluid and contradictory nature of developments in interwar Christianity, I am not convinced, particularly for Central Europe, the region about which I know most, that secular-religious struggles were becoming marginal events. Certainly, in France, Germany, and Italy many liberals found anticatholicism less appealing after the First World War. But there were new anticlerical agents such as the communists and National Socialists, who also happened to be anti-liberal. In the public sphere, the actions of these groups became linked to the news of anticlerical events in Mexico, Russia and Spain, thereby raising the stakes of local politics. In most of Europe anticlericalism did not lead to physical violence. Like the nineteenthcentury "culture war," it was comprised largely of acts of rhetorical violence via press, pulpit, association, and street demonstration, i.e. in the realm of culture broadly defined. 
Adopting the term "culture war" for the events of the 1920s and 1930s is predicated on the thesis that secular-religious conflicts continued to be defining components of the historical dynamic. The added benefit of its adoption is that enables us to borrow the methodological approaches developed for the study of nineteenth century "culture wars." In particular it would allow us to pose new questions to the growing literature on the relationship of religion to the struggle of political ideologies. ${ }^{10}$ While a number of scholars have explored how the interwar experiences of political Catholicism contributed to Christian Democracy, ${ }^{11}$ and many more have examined church accommodation with fascism, little attention has been given to the relationship of Christianity and communism.

Why have we not yet seen a study of the churches' engagement with secularism comparable to church historian Hubert Wolf's examination of the way the Vatican grappled theologically with National Socialist racism? ${ }^{12}$ Certainly, the relationship of the churches to National Socialism was more complicated and morally problematic than its relationship to communism. The title of Wolf's book Pope and Devil evokes the Faustian elements of the relationship. Yet, the title is somewhat anachronistic, given that when Christian leaders spoke of the devil or the Antichrist in the 1930s, they most often identified him not with Hitler, but with "godless Bolshevism." A comparison of the paired encyclicals of March 1937 Mit brennender Sorge and Divini Redemptoris make it clear that when confronted with Soviet atheism, the Vatican considered Nazism the lesser evil. It may be that Christian anticommunism appears so obvious in retrospect that scholars have not considered it worthy of further investigation. Given, however, that nineteenth-century liberalism and ultramontanism first produced their full articulation through their interaction, then interwar Christian antibolshevism should not be taken for granted, but rather studied in its evolving relationship to communist anticlericalism. This interaction was particularly important in the periods of increasing political polarization, such as confronted Germany in the late 1920s and early 1930s, when the culture war was not a mere appendage to ideological conflict, but instead helped shaped the horizons of expectations and contributed to the formation of political ideas on the left and the right. 
Study of the interwar Kulturkampf as a transnational phenomenon remains an agenda for future research. I would like, however, to propose two preliminary hypotheses, which I will explore through my chosen case study. First, anticlericalism was a key arena for socialist, communist, and socialemancipatory movements of this period. Although I am using Europe as my framework here, the struggle against religion was global. As Peter van der Veer has argued, the role of religion in the perceived modernization gap produced in the colonial encounter provided fuel to anticlericalism in places such as China and India. ${ }^{13}$ In addition, given the convergence of global communism with anticolonialism, it is likely that anticlericalism played a larger role in the global history of the twentieth century than has been hitherto recognized.

Second, the fear of secularism stimulated the organization of national and international networks of conservative Christians, both lay and clerical. These networks were for the most part not explicitly fascist, yet antisecularism facilitated rather than hindered collaboration with fascism. Christian apology formed a crucible in which a number of religious-social discourses and theological-political strategies were forged. Although most succumbed to the more powerful political ideologies and are now largely forgotten, these Christian strategies and discourses represent signature elements of the religious and political culture of the period.

Because these two developments emerged out of the conflicts between Christians and secularists on the local, national and international level, their history should be studied together. In the interest of this $J R H$ special issue on transnational anticatholicism, I have chosen as a case study the interactions of communists and Catholics in the Vatican, the Soviet Union and Germany. As a consequence, many of the crucial actors in the overall European "culture war," i.e. Protestants, Orthodox Christians and Jews, as well as socialists, liberals, and National Socialists, appear only as contextual factors in my account.

The chief source base for this essay are materials from the Vatican archives, followed by information held in German state and ecclesiastical archives. Only a handful of German-language documents from the archive of the Communist International (Comintern) in Moscow have been consulted. ${ }^{14}$ The result is a view of the Kulturkampf largely from the perspective of a handful of Vatican decision 
makers and their German correspondents, which shows how anticatholicism was registered by the leading Catholics of the day, and how they responded with antibolshevik messages expressed in different spheres to specific target audiences.

This essay investigates two phases of Soviet-Vatican interaction. During the 1920s both sides engaged in diplomatic efforts to find a modus vivendi between Moscow and the Holy See. After the definitive break in relations and the launching of the pope's "crusade of prayer" in 1930, Germany shifted from being the main conduit of diplomacy to a chief battleground in a bitter transnational propaganda war between communists and Catholics.

\section{Case Study: Kulturkampf in the triangle Rome-Moscow-Berlin}

One can begin the entangled history of anticatholicism and antibolshevism in the late nineteenth century, when encyclicals condemned socialism and the first Bolshevik leaders imbibed the anticlerical and anticatholic literature popular among the European workers' movement. Prior to the First World War, some Bolsheviks, such as novelist Maxim Gorky and future Commissar of the Enlightenment Anatoly Lunacharsky, actively promoted the intellectual philosophies of Western Freethought, from the monism of Ernst Haeckel and Ernst Mach to the positivism of Auguste Comte. ${ }^{15}$

In course of the Russian Revolution and Civil War Metropolitan Tikhon of the Orthodox Church anathematized the Bolshevik government, which, for its part, targeted churches and church leaders for violent suppression. Leading Vatican figures had direct traumatic experiences of revolution. As nuncio in Warsaw, Achille Ratti (later Pius XI 1922-1939) contemplated possible martyrdom as the advancing Red Army threatened to overrun the city in 1920, while nuncio Eugenio Pacelli (later Pius XII 1939-1958) fled Munich to escape the short-lived socialist revolution there in 1919.16

Despite mutual hostility, the Vatican and Moscow had reasons to come to an understanding. Vatican diplomacy was guided by two major considerations. First, it sought to secure pastoral access and care for the estimated 2.200,000 million Catholics and 65, 000 practitioners of the Oriental rites living under Soviet domination. ${ }^{17}$ Second, it sought to make the most of the crippling blow 
inflicted by the Bolsheviks on the Russian Orthodox Church. Pius XI hoped to overcome the schism of 1054 , not through the union of the churches desired by many Orthodox believers, but rather through the conversion to Catholicism of the Russians living in the USSR and in exile. ${ }^{18}$

These interests led the Vatican to temper its condemnation of the Bolsheviks and thereby open itself up to charges of opportunism, such as that made in 1924 in the pages of the left-wing journal Die Weltbühne, where Friedrich Sternthal accused the Vatican of remaining silent to the shooting of priests, due to its "enormous interest in not losing the connection with the Russian rulers." 19 Without embracing Sternthal's cynical view, one can nonetheless conclude that the Russian Revolution, like other aspects of the postwar order, provided opportunities as well as threats to the Catholic Church.

The Soviet Union, for its part, entered into negotiations with the Vatican out of its desire for diplomatic recognition and in order to smooth relations with those states with large Catholic populations. Avoiding making an enemy as powerful as the Vatican may have played some role in the uneven treatment of the religions of Russia. According to a Vatican report citing information obtained from the antireligious museum in Leningrad, some 54\% of Orthodox churches, but only $6.8 \%$ of Roman Catholic churches had been closed by 1927 or $1928 .{ }^{20}$

Germany emerged as the chief diplomatic channel for Soviet-Vatican negotiations for two reasons. First, the military cooperation between the Red Army and the Reichswehr established at the treaty of Rapallo in 1922 made Germany a key strategic partner for the Soviets. Second, the powerful position of the Catholic Center Party in successive governments, gave the Vatican direct access to leading Catholic politicians of Weimar from former Chancellor Joseph Wirth, to party chairmen Wilhelm Marx and Prelate Ludwig Kaas. As nuncio to Germany until 1929, Eugenio Pacelli became a key go-between in Vatican diplomacy. He received papal direction via Secretary of State Pietro Gasparri, but also through Michel d'Herbigny, a French Jesuit, who rose quickly through papal favor to lead the Commissio pro Russia, an institute dedicated to the Church's Russian mission. 


\section{Soviet religious policy in the 1920 s}

As historian Daniel Peris and others have shown, Soviet religious policy varied considerably in the 1920s. In the chaotic period following the Civil War, the Bolsheviks had focused on disabling the hierarchy and fomenting a schism within the Russian Orthodox Church. During the period of the New Economic Policy (NEP), which was marked by efforts to stimulate the economy and win popular support for the new regime, limited private enterprise was reintroduced. In line with overtures being made to the peasantry, some party leaders argued for limited toleration of local church congregations, particularly the growing sects. At the same time, the party supported broad antireligious education, and in 1925 created a nominally voluntary organization, the League of the Godless. ${ }^{21}$

League policy fluctuated between seeking to eliminate religion via propaganda and its direct suppression through violence. The decisive swing from a "culturalist" to an "interventionist" mode in 1929 reflected the overall shift in the regime associated with collectivization and the building of socialism. ${ }^{22}$ Historians have tied this "great turn" to Stalin's consolidation of power, but also to tensions arising from the contradictions of NEP. Homologous contradictions manifested themselves in the religious sphere. On the one hand, there was mounting demand within the state for antireligious action, which is revealed in the forced growth of the League, now called the Militant Godless, from 100,000 members in 1925 to 700,000 in $1929 .{ }^{23}$ On the other hand, a "religious wave" was sweeping the Soviet Union, which saw the recovery of Orthodox churches and the flourishing of many grass roots cults. Ludwig Berg, the priest in charge of the Vatican mission to Russian émigrés in Berlin, reported that the Ukrainian Orthodox church had succeeded in building a church apparatus qualitatively and quantitatively as good as the government's antireligious organizations. In the city of Kharkov, the number of church practitioners has risen dramatically from 10,000 in 1925 to 34,000 in $1927 .{ }^{24}$

\section{Rising tensions 1927-1929}

By 1927 diplomacy between the Vatican and Moscow had stalled. Pacelli wrote to d'Herbigny that only the directive of Gasparri to "not rip the tenuous thread" connecting the Vatican to Moscow led him to agree to meet Georgy 
Chicherin, the Soviet Commissar for Foreign Affairs, for a second time in 1927. D'Herbigny complimented Pacelli on the sacrifice he made in overcoming the repugnance of having to deal with representatives of a regime that "had stirred up the universal execration of the civilized world." 25 The previous year, d'Herbigny had undertaken a disastrous mission to Russia. Following his secret consecration as bishop by Pacelli in Berlin, d'Herbigny had consecrated further bishops in Moscow. When this became know to the Soviet authorities, the Jesuit was expelled and increased restrictions placed on Vatican activity inside Russia. $^{26}$

German Catholic politicians also felt frustrated at having to suppress their growing hatred of the Soviet regime for reasons of state. Center party chairman and prelate Ludwig Kaas told former chancellor Joseph Wirth in 1929, "I could describe the current Russian regime as nothing other than a 'satanic synagogue', whose disappearance would be a blessing not just for Russia, but for the whole world." Here he assumed that "the Catholic Wirth" was of the same opinion as "the Catholic Kaas." On the other hand, as a politician, he recognized the need ensure peaceful coexistence with a powerful neighbor. Kaas did not think that a public campaign in Germany would serve either end. Given their "pathological fear of a united Western front," the Soviets would "doubtlessly view a collective action, even of a purely religious nature, as a political concentration against Russia and react accordingly." Kaas offered to pick up confidential negotiations with Chicherin on behalf of the Church, for which he sought Pacelli's permission. ${ }^{27}$

The Vatican used German politicians like Wirth and Kaas to bring the German Foreign Office to advance the Vatican's agenda. However, like their French, Italian and Polish counterparts, German diplomats were hesitant to do more than raise the issue of religious persecution with the Soviets. As long as the Rapallo Treaty remained a pillar of German foreign policy, the Foreign Office was not willing to publicly condemn this sensitive aspect of Soviet domestic politics.

Where elite connections failed to produce results, the Vatican placed pressure on both the German and Soviet governments by appealing directly to the German Catholic community via the press. Vatican archives contain at least two examples of articles written by officials in d'Herbigny's Commissio pro 
Russia and planted in German Catholic papers. On November 17, 1928 Pacelli reported back to Rome that "thanks to intervention of influential personages" he had succeeded in publishing in Germania, the flagship paper of the Center Party, a declaration by "German Catholics" against Soviet religious persecution. The perturbed response of the Foreign Office shows that the article hit its mark. Franz von Papen, an archconservative member of the Center Party and majority shareholder of Germania, reported to Pacelli with some glee that the Foreign Office "repeatedly questioned me regarding the origin of this attack and is obviously not in agreement with its content. I responded to the Foreign Office that this notice, which arrived to us from a confidential source, certainly corresponds to the opinion of the entire Catholic population of Germany and that in the future we intend to represent the interests of the Church against the current policy in a much sharper fashion." 28 The Foreign Office had good reason to suspect Vatican involvement, given that the demands listed in the declaration corresponded closely to those forwarded by the Vatican to the Foreign Office for use in ongoing negotiations. Chicherin later told Wirth that articles in Germania had led him to the opinion that the Center Party was turning away from Rapallo, a development that he ultimately laid at the doorstep of the Vatican. ${ }^{29}$

The article also sought to embarrass the Soviets and the German Foreign Office by revealing negotiations between them over a loan. Wirth and Pacelli expressed hopes that mounting foreign debt would drive the Soviets to make concessions in the religious sphere. ${ }^{30}$ Events proved Wirth and Pacelli wrong. Rather than moderating policies, the Soviets tried to surmount the balance of payments crisis by increasing grain exports though forced requisitioning coupled with a drive for collectivization.

The Bolsheviks staged collectivization as a rural revolution that targeted the wealthier peasants, the so-called kulaks, as class enemies. Based on purported crimes, such as non-fulfillment of inflated grain production quotas, Soviet officials descended on villages, performed impromptu show trials, stripped kulaks of their grain and their property, and sent them into exile. Many local populations refused to accept the staging and rose up against the state in civil insurrections, which only confirmed to Bolsheviks that they were indeed locked in a life and death struggle with capitalist enemies. ${ }^{31}$ 
The April 1929 decree "on religious associations" created the legal framework for a broad persecution of churches and sects. It declared illegal key elements of religious practice, such as youth instruction and the distribution of literature. It also required local church elders to assume personal responsibility for church upkeep, taxes and insurance, expenses that could--analog to the high quotas for grain--be arbitrarily increased to force individuals into arrears and open them to legal prosecution for an act of hostility to the state. According to historian Sandra Dahlke, the chief aim of the 1929 decree was to destroy religious congregations as sites of "potential opposition to agricultural collectivization." 32

The antireligious dynamics generated by the state-driven civil war narrowed any negotiating room previously enjoyed by Soviet diplomats. When in 1924 the Soviet ambassador to Germany Nicolai Krestinski received a list of imprisoned priests that the Vatican wished released, he replied to Pacelli that the church's assumption that these individuals had not committed crimes was based on prejudice. Nonetheless, he offered to intervene on behalf of the Holy See out of "humanitarian concern and sense of justice."33 By contrast, when Maxim Litvinov, the new Commissar for Foreign Affairs, discussed imprisoned priests with German ambassador von Dirksen in 1930 he did not attempt to argue for the individual guilt, implicitly conceding that they were being arrested merely because they were clergy. When von Dirksen insisted that the Germanspeaking Catholic population of the Soviet Union was "loyal and fully unpolitical," Litvinov said that he had no hope of surmounting the domestic obstacles that would allow the release of their priests: "Given that the Soviet government has an antireligious orientation, the local authorities would simply not understand if action were taken against the Orthodox Church and its priests, while next door the German Catholic priests were left untouched."34

The targeting of church leaders proved an effective way of breaking up village solidarity and eliminating local elites. Anticatholicism, as a variation of anti-religious discourse, was mobilized in the staging of rural class war in Catholic regions of the Soviet Union. An example is provided by a series of articles that appeared in the German-language newspaper Das Deutsche Dorf on a purported "anti-Soviet kulak group" operating in four German villages of the 
North Caucasus in 1929 under the direction of Catholic priest Josef Kelsch. Following their arrest by the secret police (GPU), the seventeen "wealthy" ringleaders admitted to a series of "outrageous crimes." Some of the "crimes" of which Kelsch was accused--urging parents to keep their children out of the Soviet school, forbidding girls from joining non-Catholic youth groups, ostracizing those living out of wedlock--seem plausible given the selfunderstanding of many rural Catholic clergy of the day. However, when the article quotes Kelsch as saying, "I am a principle supporter of the bourgeoisie, because they support religion and faith," Marxist jargon was clearly being placed in his mouth in order to justify punishment and, most importantly, to produce a didactic lesson for the readers. ${ }^{35}$

The journalists and police interrogators who authored this lesson mobilized a host of specifically anticatholic clichés to describe Kelsch. He used "medieval methods" in youth instruction, and acted like a "real Jesuit" against the village poor. Those he considered guilty of sins had to kneel in church "or stand for hours in the church yard lightly clad in the bitter cold with outstretched hand--like Christ on the cross." The press reports peaked in the far-fetched allegation that Kelsch had established a Dominican order for boys and a Jesuit order for villagers to engage in secret ant-Soviet violence. ${ }^{36}$ The final article completed the lesson: "The conclusions that we must take from the Kelsch story are clear: merciless struggle against church and clergy of whatever type."

When d'Herbigny learned that Kelsch's brother lived in Bavaria, he wrote to Pacelli that this "might provide a good occasion to move the opinion of German Catholics a bit."37 In November 1929, d'Herbigny commissioned another member of his order to write an article on "the persecution of Christians in Russia," which the German Jesuit and prominent intellectual Friedrich Muckermann sent out via the Catholic wire service. Muckermann assured Pacelli that he could get it into many German newspapers without its true origin being discovered. ${ }^{38}$ The hard-hitting article announced that the "persecution of the Christians and the struggle against all religion appear to be moving towards their apex." Not only were Catholic priests disappearing to the concentration camps on the Solovetsky islands in the White Sea where lethal winter conditions mean "certain and rapid death," the regime was now eliminating church 
buildings, either through demolition, excessive taxation or their transformation into public spaces. This last tactic often went awry, such as occurred when a Komsomol group took over an orthodox church in the Donetsk region in July 1929. In the ensuing battle with local miners, seven Komsomols and eight believers were killed. ${ }^{39}$

By the time this article was printed, Pope Pius XI had already told d'Herbigny that he had given up hope for future diplomacy. In December 1929, they began to plan a high-profile campaign against religious persecution in Russia, the name of which "crusade of prayer" emphasized the break in Vatican strategy from one of quiet negotiation to open hostility towards the Bolshevik regime. This "crusade" was announced in the Pope's public letter to Cardinal Pompilj in February 1930 and initiated in a public mass on St. Peter's Square on March 18 that drew a crowd of 50,000, including many foreign leaders, such as Ludwig Kaas. ${ }^{40}$

\section{Freethinkers in Central Europe}

While the inability to check the systematic persecution of clergy in the Soviet Union was the primary factor behind decision to announce the papal "crusade," the church was also concerned about communist promotion of anticlericalism internationally, particularly in Germany. Bishop d'Herbigny saw in the recent foundation of German-language newspapers in the Soviet Union an effort to reach readers in Germany and Austria with antireligious propaganda. The German Ministry of the Interior confirmed a year later that Soviet Godless journals were being sold in Berlin and that antireligious programs in German were being broadcast on the international service of the Moscow trade union radio station. ${ }^{41}$ Such efforts to foment anticlericalism in Germany conformed to the Comintern policy of exporting Soviet practices for emulation by Communist parties worldwide. To a significant degree, however, the Soviets were also responding to the opportunities offered by the ongoing anticlerical activities of the Central European Freethinkers.

Whereas the socialist-identified wing of Freethought was only one of many secularist endeavors in Wilhelmine Germany, after the First World War it came to dominate the secularist scene. During the revolution, several Freethinkers, including Adolph Hoffmann, Ernst Däumig, and Max Sievers rose to political 
prominence in the Independent Socialist Party (USPD). After pushing the USPD to accept the conditions of the Third International imposed by Lenin, they took key positions in the United Communist Party in 1920 but almost immediately ran afoul of the Comintern and were effectively ousted in 1921. Some rejoined the SPD, like Sievers, who became the chairman of Germany's largest secularist organization, the Association for Freethought and Cremation (VfFF). Although dominated by SPD-members, until the late 1920s German Freethought was proud of being a revolutionary proletarian movement that managed to unite communists, left-wing social democrats, and members of the splinter groups of the radical left. ${ }^{42}$

When communist and socialist Freethinkers from Germany, Austria and Czechoslovakia met to form an International of Proletarian Freethought (IPF) in the Czech town of Teplice in 1925, the Russians were nowhere to be seen. The Comintern approved communist participation, but when the delegate from the Soviet League of the Godless failed to take his reserved seat at the meeting of the IPF executive in Leipzig in December, Czech leaders wrote to the Comintern, complaining that without Russian involvement, the Czech and German communist Freethinkers could not sustain their plan to gain control of the IPF. 43

Archival data shows that only with the beginning of the shift in Comintern policy known as the "Third Period" in 1928 did the Russians make a concerted effort to wrest control of the IPF and the national Freethought movements from the Social Democrats, now branded "social fascists." The VfFF was an attractive prize. It had expanded enormously in the course of the 1920s thanks to its cremation insurance policy and by 1928 it had over half a million members, making it one of the wealthiest and largest socialist cultural organizations. German Communist Party (KPD) directives of 1929 and 1930 make clear that one of the aims of increasing the anticlerical activism was to outflank the SPD and draw its more radical adherents to the communist side. ${ }^{44}$

\section{Organizing the Culture War}

With the breakdown of Soviet-Vatican relations and the removal of diplomatic inhibitions, each side launched enormous propaganda campaigns to foment anticatholic and antibolshevik prejudice and action in their respective spheres of influence. These spheres overlapped geographically in Germany. 
The communist response to the "crusade of prayer" was to designate the Pope as the spiritual ringleader of the international encirclement of Western powers feared by the Soviet Union. On February 11, the German Communist press service announced: "The Pope wants war against the Soviet Union and whoever knows the organizing effect that the Vatican exercises on all Catholic parties and governments around the globe, will appreciate the inflammatory effect of the papal manifesto." The Leningrad chapter of the Militant Godless threatened to turn the Vatican into an antireligious museum, in which "the straw puppet of the Pope will be displayed next to the straw puppet of a Siberian shaman, as a monument to a thousand years of error and papish deception." 45 On the front page of the French communist daily L'Humanité former Comintern head Nicolai Bukharin decried the March atonement mass in Rome:

this wild dance of the cannibals of the counterrevolution, these howls of the [...] clerical hyenas that accompany the rattling of sabers, spurs, and censers do not astonish anyone. This is the 'moral' preparation for the offensive against the Soviet Union. ${ }^{46}$

Germany witnessed a dramatic increase in anticlerical action in early 1930, undertaken primarily by communists. The most audacious incursions into church territory in March 1930, such as the interruption of a Berlin church service with shouts of "Red Front!" or the overnight smearing of nearly all of the churches in Krefeld with red paint, were tame by comparison to the events taking place in the Soviet Union. ${ }^{47}$ But the public assault on the authority of the churches and the sanctity of their symbols was novel and frightening. Whereas the Freethinkers had long ridiculed the churches, at the end of the 1920s they increasingly did so in public and with a high degree of vulgarity. Anticlerical brochures replaced reasoned argument was crude caricatures. [see Fig. 1]. Agitprop theater gained in popularity, and, according to Berlin Police President Albert Grzesinski (SPD), anticlerical skits made this one of the "most effective and at the same time ugliest method of KPD agitation." In a 1931 report, Grzesinski described a performance in Essen in which three clerics appeared (Catholic, Protestant and Jewish) and sang a song against workers that ended with the refrain, "Yes, you can pray again, as we kick you in the arse; when hunger's got the prolet by the throat, we get a raise from the republic." ${ }^{48}$ 


\section{[insert fig. 1]}

The KPD embraced the church-leaving (Kirchenaustritt) campaigns of the Freethinkers. Because the state only collected church taxes from registered members of the confessions, communists argued that Austritt dealt a financial blow to the churches. More important, however, were the politics of church statistics. In a state-monitored confessional system, the size of the church's flock was measured by members rather than attendees. Thus church leaders were alarmed by the marked jump in the number of Germans leaving the churches, from some 186,000 in 1929 to roughly 250,000 in 1930. Although Protestants made up the overwhelming majority of those embracing a confessionless status, Catholic Church leaving increased more sharply in $1930 .{ }^{49}$

The rising invective between the communists and the Christian churches and their political allies hastened the complete breakdown of cooperation between SPD and KPD Freethinkers. When the KPD failed to take over the VfFF, it launched its own Freethought movement. The same process occurred within the IPF. Following the expulsion of the leader of the Czech communist Freethought organization Swaz from the IPF's executive committee in January 1930, the Czech, German and Austrian Communists formed an International Freethought Faction, which they placed under control of the KPD and the Comintern. At the 1930 IPF congress, they walked out to form their own communist IPF.50

While the Soviet godless journal Bezboznik contained numerous stories against the Vatican from the spring of 1930 onwards, only in the winter of 19301931 did images of the Pope come to dominate the covers and full-page posters contained in the magazine. A poster from April 1931 shows how Soviets linked all of their enemies to religion [see fig. 2]. Out of an Easter egg appear in succession the "kulak," the "sub-kulak" (a term used to designate small farmers who resisted collectivization), the "wrecker," and finally foreign "intervention" represented by the triumvirate of military, capitalists and papacy. The poster unwittingly charts the successive phases in instrumental use of antireligion for political ends. Anticatholicism only emerges as a dominant discourse in the last phase, at the point at which the Soviet regime had largely eliminated its 
domestic enemies and was using the threat of foreign intervention to justify continuing coercion. ${ }^{51}$

\section{[insert fig. 2]}

\section{The Catholic antisecularist campaign}

Concerned that the "crusade of prayer" would lead to the further persecution, the freshly appointed Secretary of State Pacelli asked Western leaders in February 1930 to assure the Soviets that the Vatican was not engaging in politics. Yet, as Mussolini made clear in his subsequent meeting with the nuncio for Italy, conservatives across Europe had understood the letter precisely as an invitation to launch a political campaign. Mussolini bragged that he had been approached from various quarters to lead the charge against Russia. However, because he had already eliminated Marxism in Italy, Mussolini declared that he had nothing to gain by sticking his neck out. "If the [other] powers throw in the ball," he told the King of Sweden over lunch, "I will be one of the strongest footballers." But as a more straightforward undersecretary of state told the nuncio sotto voce before the meeting: "L'Italia non può far niente."52

This exchange between the nuncio and Mussolini reveals the effect of the "crusade" on European politics. It did not change governmental diplomatic strategies, but it did authorize clerical and lay leaders to give free reign to their antibolshevism. Within the church itself, many bishops and priests were eager to relay the Pope's message to their local populations. On the day of the publication of Pope's letter, the leaders of Germany's two Catholic episcopal conferences made headlines by calling for action to halt the godless movement. In a mass in Munich Cardinal Faulhaber decried the "bloody persecution of faith" in Russia, and Cardinal Bertram of Breslau issued a decree warning of the "storm waves of godlessness" released by the "Antichrist" and that were washing over Germany. ${ }^{53}$ Bertram's invocation of the Antichrist was not exceptional in any way. Joseph Gorbach, an Austrian priest in charge of the regional social welfare organization Caritas, used the image of a red serpent twisted around the cross to adorn his brochure Russland. [see figure 1] It is difficult to imagine a more drastic biblical repertoire than the one mobilized by the Catholic clergy at that time. Some priests began to directly challenge German government policy towards Russia. Friedrich Muckermann asked provocatively in 1931: "Why don't 
we storm the cabinets and make clear that besides trade relations there is also the eternal star of Western culture! Christendom [and] the believers in god of the whole world have the holy obligation to protest to the states in order to save humanity from a new Neronic age." 54 In the spring of 1930 Catholic organizations throughout Germany held large protest meetings against godlessness. In Munich, and most likely elsewhere, apparently spontaneous demonstrations of public support for the Pope's initiative were in fact carefully coordinated with the bishops. 55

In the summer of 1930, the church laid out a more systematic strategy for combatting Russian Bolshevism and German Freethought at its annual episcopal conferences in Freising and in Fulda. ${ }^{56}$ The bishops entrusted the main responsibility for combating atheism to the People's Association for Catholic Germany (Volksverein für das Katholische Deutschland). Founded in 1890 to "defend the Christian order of society," the Volksverein was the lodestar of the universe of Catholic lay organizations. Under the energetic leadership of priest Konrad Algermissen, its apologetic department expanded greatly and developed a comprehensive strategy of trainings, public demonstrations and lectures. Between January 1930 and August 1931 it held 1,737 meetings against radicalism and conducted 76 conferences for priests on Freethought. In some dioceses $90 \%$ of the clergy were trained. The Volksverein published a range of works on freethought and related topics, from scholarly investigations to popular penny brochures. In September 1931, Catholic clergy were sent 22,000 copies of The Church in Struggle and Victory against the Godless Movement of Today, and the brochure God or Demons reached an edition of 1.2 million by 1931. ${ }^{57}$ In a series of letters trying to curry papal support for his activities, Algermissen described to d'Herbigny his method of penetrating large urban centers of German Catholicism. In Dortmund, for example, he invited the chairmen of 600 Catholic lay associations to come to a preparatory meeting, and the Bishop of Paderborn issued a pastoral letter of support. On the first fast Sunday of 1932, all priests gave sermons on "Bolshevism" and 18 demonstrations were held across the city with high attendance. ${ }^{58}$

In February 1933, Secretary of State Pacelli asked the German bishops whether they considered it opportune for the Holy Office to issue a formal 
condemnation of Soviet godlessness. Cardinal Faulhaber responded that since Hitler was using new emergency powers to crush the Freethinkers and had already imprisoned 2,000 of their leaders, such a declaration was superfluous and would only further stir up Communist anticatholicism. The Bishop of Bamberg found it superfluous for another reason. Given the church's efforts, "today there can be no faithful Catholic who does not recognize the threat of godlessness and has not joined the battle ranks of Catholic Action."59 In other words, after three years of a well planned campaign, the antibolshevik and antisecularist message had reached into every Catholic home via pulpits and newspapers, popular meetings and even radio broadcasts. Given the steady stream of anticatholic articles and cartoons in the Communist press and the appeals for church leaving in the courtyards of worker tenements in many German cities, it can be assumed that the communist community had likewise been saturated.

\section{Local impacts of transnational struggles}

In this final section, we turn to the impact in Germany of the transnational struggle. In each case, the ostensible target of anticommunist and anticatholic agitation --the KPD or the Catholic Church--was not the main victim. While the crude anticlericalism of the KPD alienated most of the German population, it reinforced solidarity within its urban, working-class base. Erich Honecker (1912-1994), the later leader of East Germany, recalled the importance of disputes between atheists and Christians in his socialization as a young communist in his hometown in the Saarland in the 1920 s. ${ }^{60}$

Catholic leaders also discovered in this struggle a means of energizing the base. "Just as the Kulturkampf once purified and steeled religious life, [...] so the great trials of our day will prove to be a source of blessing for us," wrote priest Richard Bigenwald of the Volksverein in a model sermon against godlessness to be read for the feast of "Christ the King" in October 1931.61 As had occurred in the 1870s, the church hoped that anticatholicism would reverse the dissolution of the catholic social milieu. A report on Freethought at the Fulda Bishops conference in August 1930 found that because "the boundary between socialist and non-socialist lifestyles appears to be eroding more and more in [confessionally] mixed industrial regions," the solution had to be not just a 
division of spirits, but also "a certain division in practical life and action." Concretely, the author recommended opposing mixed marriage, discouraging Catholics from moving to the cities and strengthening church control over primary schools. ${ }^{62}$

The main victims of the struggle over religion in Germany were those political movements that supported democracy and a liberal, constitutional state. In particular, this Kulturkampf threatened the two political parties, the SPD and the Catholic Center Party, whose cooperation formed a bulwark against authoritarian solutions to Germany's political and cultural crisis. Coalition government between SPD and Center formed the basis of the Weimar democracy and until 1932, the parties jointly governed Germany's largest state, Prussia. Given the centrality of anticatholicism to European socialism, cooperation with the Center Party was a sore point with socialist Freethinkers. Many bucked party discipline and voted against the Catholic Wilhelm Marx, who ran as the coalition candidate against the conservative Junker Paul von Hindenburg in the presidential elections of 1925.63 Precisely in its religious politics, the SPD was vulnerable to communist criticism and to the absurd charge that it was cooperating with fascists. As part of his coalition agreements with the Center Party, the socialist governor of the state of Prussia Otto Braun signed a concordat between Prussia and the Holy See in 1929. The communist press linked this to the Lateran Accords signed with Mussolini the same year.

It is somewhat paradoxical that the Catholic Center Party was perhaps the major victim of the culture war, given the prominence of its politicians as the leaders of German antisecularism. However, the war against godlessness exacerbated divisions within German political catholicism and its relationship to both episcopate and the Vatican. One can divide the Center party politicians into three groups: those left and moderate supporters of Weimar democracy, such as Joseph Wirth and Wilhelm Marx, the conservative Catholics, such as Georg Schreiber, Ludwig Kaas, and a group that historian Larry Eugene Jones has dubbed "Catholic conservatives." Whereas conservative Catholics sought to work within the existing parliamentary system and thus accepted the necessity of pragmatic coalitions, Catholic conservatives "had deep reservations about the system of parliamentary democracy that Germany had inherited from the 
November Revolution; all favored a reorganization of the state, society, and economy along corporatist lines; and all advocated, if not a restoration of the monarchy, then at least the establishment of a more authoritarian political order that would no longer be so dependent upon the vicissitudes of the popular will."64 The coalition with the SPD was particularly galling to Catholic conservatives like Franz von Papen and Prince Aloys zu Löwenstein, the head of the Katholikentag, Germany's annual gathering of Catholic organizations.

Pius XI shared their misgivings about political catholicism. In 1924, the Pope had forced the leader of the Partito Populare Italiano to stand down and prohibited the party from aligning itself with socialists to oppose Mussolini. ${ }^{65}$ In May 1925, four weeks after Wilhelm Marx lost to von Hindenburg in the run-off presidential election, the Pope issued a stark warning to the German bishops via the Secretary of State and demanded that they ask Catholic politicians to examine seriously "in the light of the unfailing principles of the Church whether alliances with socialists, who have always be adversaries of Catholic ideas, denigrating them as reactionary and obscurantist, in the long term do not threaten to become dangers for ecclesiastical authority, which is called upon to watch over social and political Catholic Action."66 In a letter to Pacelli, Marx expressed irritation at being put in the humiliating position of having to justify his party's policies and blamed "certain aristocratic circles" for poisoning the Pope's ear. In the end, Pacelli and Gasparri accepted Marx's rationale, but they put the party leadership on notice that such coalitions should not become the norm.

The collapse of the Weimar Germany's last coalition government and the formation of the first "presidential" government under the conservative Catholic Heinrich Brüning in March 1930 encouraged Catholic conservatives in their efforts to permanently replace the Weimar "system" with an authoritarian regime. Antibolshevism and antisecularism proved to be key areas around which the "national opposition" could and did organize, as shown by the example of the German League for the Protection of Western Culture (Bund zum Schutz der Abendländischen Kultur). This pressure group brought prominent Catholic and Protestant aristocrats, such as von Papen and zu Löwenstein and Protestants Freiherr von Gayl and Werner von Alvensleben, together with high-ranking 
clergymen of both faiths and several former cabinet ministers. The League enjoyed direct connections to President von Hindenburg's entourage and to the strong man of the Reichswehr, General Kurt von Schleicher. It prefigured the "Cabinet of Barons" under Chancellor von Papen that would replace Brüning in June 1932.

The League held a demonstration "for culture and faith against the world revolution" in the Berlin Sportpalast on 16 November 1930, which led to a direct confrontation of antibolshevism and anticlericalism. Among the 8,000 to 9,000 spectators were some 800 members of the KPD, who threw leaflets from the balconies and disturbed throughout. The speeches of the Greek Orthodox priest Seraphim and the Protestant General Superintendent Karow were met with choruses of "Down with the church!" and "Long live Karl Marx! Long live Bolshevism!" When the communists struck up "the Internationale," they were drowned out by the singing of the national anthem. ${ }^{67}$

The presence of leading Center Party politicians in the Bund, including von Papen and Georg Schreiber (later also MP Joseph Joos), rang alarm bells with the Soviet Foreign office. They correctly saw in it an attempt to overturn the Rapallo treaty and bring Germany into an anti-Russian alliance. Papen had already taken part in meetings with French conservatives aimed at promoting French-German rapprochement based on the common threat of Bolshevism to Christian civilization. ${ }^{68}$ In January 1930, he called on France to join Germany or it would find itself "standing before the ruins of a fully godless, spiritless, Bolshevized Europe." ${ }^{69}$ The Bund developed close ties to Swiss-based Entente Internationale Contre la Troisième Internationale. Led by the Protestant Swiss lawyer Théodore Aubert and the Russian Orthodox physician Georges Lodygensky, this organization had been building up an international and ecumenical network of Christian conservatives since its foundation in $1924 .{ }^{70}$ Although the Vatican agreed with the idea that Christianity was the true foundation of Western Civilization and supported French-German reconciliation, it steadfastly refused to support ecumenical efforts such as the League or the Entente Internationale. ${ }^{71}$

The manner in which the logic of the Kulturkampf worked against the Center Party and ultimately against the Brüning government is shown by the May 1932 decree outlawing the Communist Freethinkers. Because it spared the 
socialist Freethinkers, the reactionary parties in the Reichstag immediately held this up as proof of collusion between SPD, Center, and the Brüning government. Leading church leaders joined in the chorus of complaint. Algermissen faulted the Brüning government for half-measures, and Nuncio Orsigno wrote that because it did not ban the socialist freethinkers "it has not gained the complete support of the Catholics and in reality it does not merit special recognition." For Orsigno this failure revealed more than the errant coalition policy of the Center party; it revealed the weakness of the liberal state, where "the unlimited freedom of association guaranteed by the constitution of Weimar, also in the field of antireligion, significantly hems [the government's ability to take] repressive action."72

Mainstream Catholic politicians found themselves in a quandary and were demoralized by the charge that their struggle against godlessness in the public sphere was hypocritical because they continued to uphold the freedom to agitate enjoyed by the socialist freethinkers. Some conservative Catholics, most notably von Papen, parted ways with Center and sought authoritarian solutions with traditionally the anticatholic German National People's Party and later with the NSDAP. Hitler promised to reverse the secularization legislation of the Weimarera socialist governments and to destroy the organizations of secularism in Germany. Both of these aims were accomplished in the first months of the "Third Reich" to the satisfaction both of the German churches and the Vatican. In a February 1934 sermon aimed at reminding the Nazis of their obligations in the Concordat signed the previous summer, Cardinal Faulhaber stated that the Pope had fulfilled his part of the bargain when he "placed the moral powers of the church at the disposal of the Führer of the German Reich for his struggle against godlessness and immorality."73

\section{Conclusion}

Anticatholic violence, first in Mexico and later in the Soviet Union, contributed decisively to the opening of a religious front in the latent civil wars that characterized interwar Europe. The threat of godlessness from outside Germany placed domestic developments in a new light for religious inspired political actors, such as Prince zu Löwenstein. In a speech prepared for a 
gathering of German Catholics in February 1930 he wrote that events in Russia showed "us finer nations of the West (Abendland), the horrendous possibilities lying in wait at the end of the development, into which we have slid with so much superior tolerance." This spurred his efforts to revise the postwar liberal order. ${ }^{74}$

The German case reveals how national contexts inflected the transnational dynamics of radical anticatholicism in the interwar period. Communists discovered in the large and wealthy Freethought movement an ideal target for their struggle against the SPD. They hoped to pry disgruntled leftwing anticlericals away from the SPD by portraying its coalition with the Center Party as proof that the socialists were lackeys of clerical fascism. For their part, German Catholic leaders willingly joined the ranks of an imagined Christian army, but they did not do so merely as agents of a crusade developed in Rome. In the international struggle, they pursued their own interests. They mobilized old ideals and through apologetic and arrived at new strategies. The imagined "Christian State" was not the ultimate result of conservative and Christian agitation. Instead, the "culture war" further destabilized the republic and added a religious dimension to a semantic landscape well suited to National Socialist efforts to reach a Christian population otherwise mistrustful of its völkisch and anticlerical elements.

\section{Captions for images}

Fig. 1. A communist and a Catholic brochure from 1930. Left: Peter Maslowski, Kulturschande über Deutschland. Right: Josef Gorbach, Russland.

Fig. 2. Covers from the monthly journal Bezbozknik (Godless), published by the League of the Militant Godless. Left: April 1931, caption: "Easter egg and its content." The eggs are labeled "XB = Christ is resurrected," "Kulak," "Subkulak," "Wrecker," "Intervention." Right: cover from September 1931.

\footnotetext{
${ }^{1}$ W. Becker, "Der Kulturkampf als Europäisches und deutsches Phänomen," Historisches Jahrbuch 101 (1981): 444.

${ }^{2}$ M. Borutta, Antikatholizismus: Deutschland und Italien im Zeitalter der europäischen Kulturkämpfe (Göttingen: Vandehoeck \& Ruprecht, 2010); L. Dittrich, Antiklerikalismus als europäisches Phänomen: Protest und Öffentlichkeit in Frankreich, Spanien und Deutschland (1850-1914) (Göttingen: Vandenhoeck \& Ruprecht, Forthcoming); A. Joskowicz, The Modernity of Others: Jewish Anti-Catholicism in Germany and France (Stanford, Calif.: Stanford UP, 2014).

${ }^{3}$ C. Clark and W. Kaiser, Culture Wars: Secular-Catholic Conflict in Nineteenth-Century Europe (Cambridge: Cambridge UP, 2003);
} 
4 O. Blaschke, "Das 19. Jahrhundert: Ein Zweites Konfessionelles Zeitalter?," Geschichte Und Gesellschaft 26 (2000): 38-75; H.-G. Haupt and D. Langewiesche, eds., Nation und Religion in Europa: Mehrkonfessionelle Gesellschaften im 19. und 20. Jahrhundert (Frankfurt a. M.: Campus, 2004).

5 While studies of predominantly Protestant countries have tended to portray Catholics as victims of a hegemonic liberalism, studies of predominantly Catholic countries have generally viewed anti-Catholicism within the context of a battle for political control between powerful Catholic forces and their liberal and subaltern opponents. T.

Verhoeven, Transatlantic anti-Catholicism; France and the United States in the Nineteenth Century (New York: Palgrave Macmillan, 2010); Borutta, Antikatholizismus; J. de la Cueva and F. Montero, eds., La secularización conflictiva: España (1898 - 1931) (Madrid: Biblioteca Nueva, 2007); G. Verucci, L'Italia Laica Prima e Dopo l'Unita (Rome-Bari: Laterza, 1996).

${ }^{6}$ M. Butler, ed., Faith and Impiety in Revolutionary Mexico; (New York, NY: Palgrave Macmillan, 2007); Cueva and Montero, La secularización conflictiva; D. Peris, Storming the Heavens: The Soviet League of the Militant Godless (Ithaca: Cornell UP, 1998). ${ }^{7}$ Although it focusses on physical violence in civil wars and does not look at culture more broadly, a useful starting point is provided by J. de la Cueva Merino, "El asalto de los cielos: una perspectiva comparada para la violencia anticlerical española de 1936" Ayer 88/2012 (4): 51-74.

${ }^{8}$ An extensive collaborative research project is underway at the University of Alcalá: "Catholicism and Secularization in 20 th Century Spain."

${ }^{9}$ M. Conway, "The Christian Churches and Politics in Europe, 1914-1939," in Cambridge History of Christianity, vol. 9, ed. H. McLeod (Cambridge: Cambridge University Press), 169-72.

10 K. D. Bracher, The Age of Ideologies: A History of Political Thought in the Twentieth Century (Weidenfeld and Nicolson, 1984); I. Kershaw, "Europe's Second Thirty Years War," History Today 55, no. 9 (2005): 10-17; S. Payne, Civil War in Europe: 1905 - 1949 (Cambridge: Cambridge Univ. Press, 2011).

11 J. Boyer, "Catholics, Christians, and the Challenges of Democracy: The Heritage of the Nineteenth Century," in Political Catholicism in Europe 1918-1945, ed. W. Kaiser and H. Wohnout (Routledge, 2004), 7-45; G.-R. Horn, Western European Liberation Theology 1924-1959 (Oxford :: Oxford University Press,, 2008); S. Kalyvas, The Rise of Christian Democracy in Europe (Ithaca: Cornell Univ. Press, 1996).

12 H. Wolf, Pope and Devil: The Vatican's Archives and the Third Reich, trans. K. Kronenberg (Cambridge, Mass.: Harvard University Press, 2010).

${ }^{13}$ P. van der Veer, "Smash Temples, Burn Books: Comparing Secularist Projects in India and China," in Rethinking Secularism, ed. C.Calhoun, J. VanAntwerpen, and M. Juergensmeyer (Oxford [u.a.]: Oxford Univ. Press, 2011), 270-81.

14 For more substantial treatements of Soviet-Vatican-German relations, see, L. Pettinaroli, “La politique russe du Saint-Siège (1905-1939)” (PhD, Lyon 2, 2008); H. Smolinsky, "Das katholische Rußlandbild in Deutschland nach dem Ersten Weltkrieg und im 'Dritten Reich'," in Das Rußlandbild im Dritten Reich (Cologne: Böhlau, 1994), 323-355; G. Besier, Der Heilige Stuhl und Hitler-Deutschland: Die Faszination des Totalitären (Munich: Dt. Verl.-Anst., 2004); M. Levant, "Reconquérir le Reich? Le Vatican et l'Allemagne de Weimar, des nonciatures Pacelli au Reichskonkordat (1919-1934)" (PhD, Univ. de Bretagne Occidentale, 2012).

15 I. Polianski, "Between Hegel and Haeckel : Monistic Worldview, Marxist Philosophy and Biomedicine in Russia and the Soviet Union," in Monism: Science, Philosophy, Religion, and the History of a Worldview, ed. T. Weir (New York: Palgrave Macmillan, 2012), 197-222.

16 Pettinaroli, 834. 
${ }^{17}$ Affari Ecclesiastici Straordinari (AA.EE.SS.), Russia, pos. 626, fasc. 13-18.

18 For a damning evaluation of Vatican policy, L. Tretjakewitsch, Bishop Michel

d'Herbigny SJ and Russia; a Pre-ecumenical Approach to Christian Unity (Würzburg:

Augustinus, 1990).

19 "Der weisse und der gelbe Papst," Weltbühne vol. 20, no. 17, April 24, 1924, 529-533.

20 The Jewish, Lutheran, Muslim and Baptist institutions got off even more lightly than

the Catholic Church. Cited in Ludwig Berg's report to Pacelli, Archivio Segreto Vaticano (ASV), Archivio Nunziatura Berlino (ANB), no 27, fasc. 10, fol. 1, Nov. 4, 1929.

${ }^{21}$ Peris, Storming the Heavens; W. Husband, "Godless Communists": Atheism and Society in Soviet Russia, 1917-1932 (DeKalb: Northern Illinois UP, 2000); A. Luukkanen, The Party of Unbelief: The Religious Policy of the Bolshevik Party 1917 - 1929 (Helsinki: SHS, 1994).

22 D. Peris, “The 1929 Congress of the Godless.," Soviet Studies 43, no. 4 (1991): 711.

${ }^{23}$ Peris, Storming the Heavens, 118.

${ }^{24}$ ASV, ANB 27, fasc. 10, fol. 1-61, Ludwig Berg to Pacelli, Nov. 4, 1929.

25 ASV, ANB 30, fasc. 1, fol. 174, Comm. Pro Russia, Voto del Relatore (d'Herbigny) on report of Pacelli.

26 Tretjakewitsch; L. Pettinaroli, "Pio XI e Michel d'Herbigny : Analisi di una Relazione al Vertice della Chiesa alla Luce del Materiale delle Udienze Pontificie (1923-1939)," in

Pius XI : Keywords. International Conference Milan 2009 (Berlin: LIT-Verlag, 2010), 279_ 297.

27 ASV, ANB 30, fasc. 4, fol. 215: Centoz to Gasparri, April 12, 1929.

28 ASV, ANB 30, fasc. 4, fol. 175, Franz von Papen to Pacelli, Nov. 20, 1928.

${ }^{29}$ ASV, ANB 30, fasc. 4, fol. 215: Centoz an Gasparri, April 12, 1929.

30 AA.EE.SS., Russia, pos. 626, fasc. 13-18, 1920-37, fol. 14, Pacelli to Gaspari, May 6, 1927; ASV, ANB 30, fasc. 4, fol. 238, Pacelli to d'Herbigny, 19 July, 1929.

${ }^{31}$ L. Viola, Peasant Rebels Under Stalin; Collectivization and the Culture of Peasant Resistance (New York: Oxford Univ. Press, 1996); T. Weir, "'Von Schwindel Befallen' Enthusiasmus, Inszenierung und Chaos im Stalinistischen Aufbau am Beispiel der Kollektivierung der DDR-Landwirtschaft 1952-3'," in Rausch und Diktatur, ed. A. von Klimo and M. Rolf (Frankfurt a. M.: Campus, 2006), 219-238.

32 S. Dahlke, "Einführung," "Über die religiösen Vereinigungen" Beschluß des VCIK und des SNK RSFSR , 8. April 1929 (http://www.1000dokumente.de/).

${ }_{33}$ ASV, ANB 30, fasc. 4, fol. 146, Krestinski to Pacelli, Dec. 10, 1924.

${ }^{34}$ AA.EE.SS., Russia, pos. 664 I, fasc. 62, fol. 4-6, Secret report from German consulate, Dec. 19, 1930.

${ }^{35}$ ASV, ASB 30, fasc. 4, fol. 240-242.

36 Ibid. The accusation that Kelsch founded "orders" for children is found in

${ }^{37}$ ASV, ANB 30, fasc. 4, fol. 237, d'Herbigy to Pacelli, July 9, 1929; fol. 243, d'Herbigny to Pacelli, August 10, 1929.

38 ASV, ANB 30, fasc. 4, fol. 265-267, 268. This article appeared in Katholische

Korrespondenz no. 117, Nov. 19, 1929.

$39 \mathrm{~A}$ harrowing report on the conditions in the concentration camps was passed from the Italian foreign office to the nuncio on Dec. 31, 1929. AA.EE.SS., Russia, pos. 664 I, fasc. 61, fol. 3-6.

40 Pettinaroli, "La politique russe," 813-819. Tretjakewitsch, 234.

41 Bundesarchiv, R 1501/126171, no. 146, Reich Minister of the Interior to the information services of the German states, Dec. 18, 1930.

42 The standard work on postwar German Freethought is J.-C. Kaiser, Arbeiterbewegung und organisierte Religionskritik: proletarische Freidenkerverbände in Kaiserreich und Weimarer Republik (Stuttgart: Klett-Cotta, 1981). On Däumig, T. Weir, "Between Colonial 
Violence and Socialist Worldview: The Conversions of Ernst Däumig," German History 28, no. 2 (2010): $143-166$.

43 RGASPI, Fond 495, Opis 99, Dela 41, 41-43, 74-76. I would like to thank Daniel Peris for allowing me to read his unpublished paper on the relationship of the Soviet state to the IPF.

44 On 15 January 1930, Emelian Yaroslavsky, the head of the Soviet Godless, pubished an article in Pravda calling on communists to attempt to "penetrate all antireligious parties ... to make them useful to proletarian class struggle" and to found "an international antireligious central, that will help all communist parties to lead the growing movement against religion." Evangelisches Zentralarchiv, Berlin, 7/ 3569, 105.

45 Translation found in an anonymous letter from Katowice to Card. Faulhaber, March, 22, 1930, Kardinal Faulhaber Archiv, Munich, no. 2013/1, pp 22-24.

46 Internationale Presse Korrespondenz, no. 15, Feb. 11, 1930. N. Bukharin, "La bacchanale commence... ou la déclaration de guerre du pape”, L'Humanité, April 1, 1930. ${ }^{47}$ Brochure of the Innere Mission of Bavaria, 15.4.1930. ADW, CA 1814.

${ }^{48}$ International Institute for Social History, Amsterdam, Grzesinski papers, no. 1424. 49 215,160 Protestants and 36,292 Catholics left the churches in 1930. K. Algermissen, "Die Pastorallehren aus der Statistik der Kirchenaustritts- und Freidenkerbewegung der Nachkriegszeit," Theol.-prakt. Quartalsschrift 86, no. 4 (1933): 689.

50 Russian State Archive, RGASPI, Fond 495, Opis 30, dela 685, 1-185.

51 Peris, Storming the Heavens, 110.

52 Transl. "Italy cannot do anything." ASV, Nunziatura Italia 120, fasc. 10, Russia, fol. 12, Nuncio Borgognini to Pacelli, Feb. 25, 1930.

53 "Das russische Elend ohne Gott," Aus Welt und Kirche, suppl. to Bayrischer Kurier, no. 21, 10.2.1930; U. Kaiser, Realpolitik oder antibolschewistischer Kreuzzug? Zum

Zusammenhang von Rußlandbild und Rußlandpolitik der deutschen Zentrumspartei 1917 1933 (Frankfurt a. M.: Peter Lang, 2005), 190-191.

54 "Die Tyrannen im Kreml," N. Wien. Journal, April 20, 1931.

55 See correspondence in Kardinal Faulhaber Archiv, no. 2015.

${ }^{56}$ Kaiser, Realpolitik, 208.

${ }^{57}$ H. Gottwald, "Volksverein für das katholische Deutschland," in Lexikon zur

Parteiengeschichte. Die bürgerlichen und kleinbürgerlichen Parteien und Verbände in Deutschland (1789-1945) (Leipzig: VEB Bibliographisches Institut, 1986), 460.

58 AA.EE.SS., Russia, Scatola 6, fasc. 44, fol. 94, Algermissen to d'Herbigny, April 7, 1932

${ }^{59}$ Archivio della Congregazione della Fede, Vatican, R.V. 1933 no. 15 (=1220/1933), S.O. Germaniae - Segr. di Stato.

${ }^{60}$ R. Kaiser and W. Herzberg, Der Sturz: Erich Honecker im Kreuzverhör, vol. 4 (Berlin and Weimar: Aufbau, 1991), 119-120.

${ }^{61}$ Richard Bigenwald, "Predigt zum Christ-König Sonntag: Moderne Gottlosigkeit und katholischer Glaube, Herausgegeben von dem Volksverein," AA.EE.SS., Germania IV, Pos. 585, fasc. 93, fol. 32 .

${ }^{62}$ H. Hürten, Akten Deutscher Bischöfe über die Lage der Kirche / 1918 - 1933, vol. 2

(Paderborn: Schöningh, 2007), 1067-1074.

63 Kaiser, Freidenkerverbände, 148-150.

${ }^{64}$ L. E. Jones, "Franz von Papen, Catholic Conservatives, and the Establishment of the Third Reich, 1933-1934," Journal of Modern History 83, no. 2 (2011): 275.

65 J. Pollard, Catholicism in Modern Italy: Religion, Society, and Politics Since 1861

(London: Routledge, 2008).

66 AA.EE.SS., Stati Eccl., Pos 359, fas. 248, fol. 31, Gasparri to Pacelli, May 28, 1925.

${ }^{67}$ Der Montag, no. 44, 17.11.1930; Die Welt am Abend. no 269, 17.11.1930. 
68 G. Müller, Europäische Gesellschaftsbeziehungen nach dem Ersten Weltkrieg; das Deutsch-Französische Studienkomitee und der Europäische Kulturbund (Munich: Oldenbourg, 2005), 81-304.

${ }^{69}$ Franz von Papen, "La bonne ou la mauvaise Allemagne?" Der Ring, vol. 3, no. 2 (12.1.1930), pp. 23-24

70 S. Roulin, Un credo anticommuniste; la commission Pro Deo de l'Entente internationale anticommuniste, ou la dimension religieuse d'un combat politique: 1924 - 1945 (Lausanne: Ed. Antipodes, 2010).

${ }^{71}$ AA.EE.SS., Russia, Scatola 6, fasc. 44, fol. 94, fol. 22. E. Fouilloux, Les catholiques et l'unité chrétienne du XIXe au XXe siècle. Itinéraires européens d'expression française (Paris : Le Centurion, 1982).

72 AA.EE.SS., Germania IV, pos. 585, fasc. 93, fol. 47-48, Orsigno to Pacelli, May 7, 1932.

${ }^{73}$ Sermon in Munich, Feb. 18, 1934, in L. Volk, ed., Akten Kardinal Michael von Faulhabers 1917 - 1945, vol. I (Mainz: Grünwald, 1975), 853-54.

74 "Papst Pius XI. und die Katholische Aktion," no date, Landesarchiv BadenWürttemberg, Abt. Staatsarchiv Wertheim, R-Lit. D Nr. 711. 